\title{
The Suitability of SElEcted Social Media FOR LANGUAGE EDUCATION
}

\author{
Adeleke Ayobami Gideon ${ }^{1}$ and Akpomuje (nee Folarin) Folake $\mathrm{A}^{2}$ \\ ${ }^{1}$ Institute of Education, Obafemi Awolowo University, Ile-Ife, Nigeria \\ ${ }^{2}$ Dept. of Arts and Social Science Education, Obafemi \\ Awolowo University, Ile-Ife, Nigeria
}

\begin{abstract}
This study determined the factors that influence the application of social media to teaching-learning process; investigated applicable choice of social media relevant in the teaching-learning process and; determined the impact of social media on students' language learning. Descriptive survey research design was employed. The population consist all Basics 6-9 school pupils in Osun State, Nigeria. Multistage sampling procedure was adopted. 670 pupils were sampled using stratified sampling procedure. A selfdeveloped instrument titled 'Social Media Teach (SMT)' with reliability coefficient of 0.762 was used to collect data. Pearson correlation and simple percentages were used in analysis. The study found the factors influencing application of social media to teaching-learning process include ease of access to learning materials (77.5\%); freedom of expression (62.5\%); increase interaction (language use) between peers $(60 \%)$ and; improving pupils' language skills (55\%). The factors accentuated that social media has a place in language education. Study also found some social media applications appealing to learners in language education in the study area to include Google+, YouTube, WhatsApp, Facebook, Instagram and Twitter. The study further revealed positive relationship between the integration of social media into language education and performances in school $(r=0.245, p<0.05)$. Study concludes that the integration of social media in language education will improve language skills, expressions and school performance at basic schools.
\end{abstract}

\section{KEYWORDS}

social media, teaching-learning, language-education

\section{INTRODUCTION}

Social media are Web 2.0 technologies which enhance social interaction, collaboration, and foster online communications dedicated to community-based input, interaction, content-sharing and collaboration. Kaplan and Haeinlein (2010) explained it as a group of internet-based applications that build on the ideological and technological foundations of Web 2.0, and that allow the creation and exchange of user generated contents. Adeleke (2016) examined the value measure of the internet among Nigerian secondary school students and found that, school assignments, social networking and current affairs among others were prominent reasons that influence the usage of internet. Hence, social media provides the learner with the possibility of participating in actual, real-time, relevant conversations taking place online.

Social media are describable further as a set of web based broadcast technologies that allow the democratization of content, giving people the ability to emerge from consumers of content to publishers. Without doubt, social media is used across all facets of the society -business, politics, media, advertising, security and emerging services. It has also become a key tool for provoking thoughts, dialogue and action around particular social issues. 
Kaplan and Haenlein (2010) differentiated between social media and social networking sites. They stated the six different categories of social media. Social networking sites are a type of social media and the most popular. The Social Networking Sites (SNSs) is defined by Boyd and Ellison (2008) as a web-based services that allows individuals to (i) construct a public or semipublic profile within a bounded system, (ii) articulate a list of other users with whom they share a connection and, (iii) view and traverse their lists of connection and those made by others within the system. The natures of these connections however vary from site to site and might include among others photographs, videos, music, blogs, favorites and so on. Examples of SNSs are Facebook, Twitter, MySpace and others. A range of activities however happen on social media according to Uremi, Akwaowo, and Senam (2013). It is a virtual location for interactions among individuals, groups and communities to build upon and integrate many communication tools and technologies such as e-mail, e-messaging, video-sharing and photo-sharing.

In the education industry, Lederer (2012) outlined some benefits of utilizing social media: First, she argues that social media increase student engagement and makes learners feel less intimidated at self-expressions. She believed that social media bridge communication gaps between students and instructors and thirdly that; social networking sites are veritable tools for job search, posting a resume, and researching potential employers. Other scholars have peered into other aspects of social media use in teaching-learning activities. For example, Perkel (2008) was of the opinion that social media supports new skills development and is also being used to extend opportunities for formal learning across geographical contexts. Blogging represents a growing activity among professionals and learners who appreciate blogs for their mix of informal commentary, links to resources and personal touch hence, in multi-modal forms and ways, social media offers people opportunities to share life experiences, vent frustrations, offer reflections on social issues and express themselves in a non-threatening atmosphere; it enables community involvement in locating expertise, sharing content and collaborating to build content and allow knowledge workers to extend the range and scope of their professional relationships. The instant messaging feature which let people exchange information in real time via a chat has not been beaten in recent time. This great feature can be explored for educational purpose to facilitate classroom discussions. National Association of School Psychologists (2016) affirmed that, many schools use Twitter as a communicating platform for students, parents and administrators.

In view of the foregoing, social media presents an array of merits as explored in literature. However, the purpose of this study is to relate social media with language education of the learners in Nigerian context as no previous work seemed overt therein. The specific objectives were highlighted with the following research questions including - what factors influence the application of social media to teaching-learning process in Osun state, Nigeria? Which choice(s) of social media were found relevant or applicable in the teaching-learning process? And; how does social media impact on students' language learning? These were with a view to project the utilitarian values and influential factors for the integration of social media in junior school classrooms.

\section{Methodology}

The study employed the survey research design. The population of the study encompassed all 4,136 Basics 6-9 school pupils in Ife Central Local government area during 2018/2019 academic session. Multistage sampling procedure was employed in sampling pupils across classes in primary and junior secondary. The sample comprises 670 Basics 6-9 school pupils randomly selected from three of the six compounded basics schools in the study area who were stratified into the study. A validated and reliable (0.76), self-designed questionnaire was employed in data collection. The instrument was titled 'Social Media Teach (SMT)'. It was previously used in a dissertation and has four sections: the demographic data of respondents; factors determining 
alternatives in language education; the choices of social media applicable in the process of learning; the impact of integrating social media into students' learning and; influence of social media application in teaching-learning processes. Respondents were proportionally sampled as the schools population varied from one to the other. 700 questionnaires were fielded but 670 completely filled were retrieved. Data analysis was done using descriptive and inferential statistics with frequency, percentages and simple correlation.

\section{RESULTS AND DISCUSSIONS}

The objectives of the study were purposed to relate social media with language education in Nigerian context. Specifically, it examined factors necessitating the integration of social media applications into education at basic schools' level. It also investigate the choice(s) of social media applicable into the process of teaching and learning at this level and as well, the study established the relationship between integrated social media and students' learning in language learning.

\section{Research Question 1:}

What factors influence the use of social media in language education? In order to answer the first research question, data collected on the factors influencing the use of social media in language education were subjected to descriptive analysis and the results are presented in Table 1.

Table 1: Descriptive analysis of the factors influencing application of social media in language education in Basics 6-9 school pupilss Osun, Nigeria

\begin{tabular}{|c|c|c|c|}
\hline $\mathrm{S} / \mathbf{N}$ & Items & Frequency (f) & Percentage (\%) \\
\hline 1. & I have a phone and can access social media & 550 & 82.0 \\
\hline 2. & $\begin{array}{l}\text { I access social media at cybercafé and } \\
\text { through friends }\end{array}$ & 290 & 43.0 \\
\hline 3. & $\begin{array}{l}\text { I have been given homework that involved } \\
\text { the use of social media }\end{array}$ & 450 & 67.0 \\
\hline 4. & $\begin{array}{l}\text { My teacher encourages the use of social } \\
\text { media }\end{array}$ & 408 & 61.0 \\
\hline 5. & $\begin{array}{l}\text { Social media has improved my language } \\
\text { skills }\end{array}$ & 410 & 61.0 \\
\hline 6. & I do not know how to use social media & 390 & 58.0 \\
\hline 7. & I have friends on social media & 628 & 94.0 \\
\hline 8. & $\begin{array}{l}\text { I have more freedom of expression when } \\
\text { using social media }\end{array}$ & 518 & 77.3 \\
\hline 9. & $\begin{array}{l}\text { The use of social media has affected my ability } \\
\text { to spell words correctly }\end{array}$ & 372 & 56.0 \\
\hline 10. & $\begin{array}{l}\text { Social media gives more access to leaming } \\
\text { material }\end{array}$ & 519 & 77.5 \\
\hline 11. & $\begin{array}{l}\text { I interact better with my peers when using social } \\
\text { media }\end{array}$ & 428 & 64.0 \\
\hline 12. & $\begin{array}{l}\text { Social media helps me to establish relationship } \\
\text { with students from other schools }\end{array}$ & 385 & 57.5 \\
\hline 13. & $\begin{array}{l}\text { I use social media as a means of staying away } \\
\text { from idleness }\end{array}$ & 580 & 87.0 \\
\hline 14. & $\begin{array}{l}\text { It has exposed me to useful information about my } \\
\text { subject }\end{array}$ & 427 & 64.0 \\
\hline 15. & It enables me read ahead of the class & 160 & 24.0 \\
\hline 16. & $\begin{array}{l}\text { It enables leamers to share new information with } \\
\text { peers }\end{array}$ & 615 & 92.0 \\
\hline
\end{tabular}

Table 1 showed six influential factors that weighed on the adoption of social media in language education in the Basics 6-9 school pupils within the study area. First in descending order is that the learners have friends on social media (94\%); share information with peers (92\%); find social media as means of fighting idleness (87\%); learners have access to smart mobiles $(82 \%)$; social media gives them access to learning materials $(77.5 \%)$ and; social media gives them freedom of 
expression (77.3\%). Significant cofounds showed that social media application was not influenced by just accessibility to it by learners outside personal mobiles as cybercafé and usage of third party's asset seemed not attractive (43\%) and only succeeded by the influence to read ahead of the next class (24\%). The threshold for significance is visible in the width of gap in percentages of responses as shown in Table 1.

The finding that social media enables and enhances learners more freedom of expression and interaction with peers while learning corroborates the view of Lederer (2012) who posited that social media effectively increase student engagement and build communication skills as it allow them to feel more comfortable expressing themselves in a less intimidating environment. Communication especially between teachers and learners can thus be enhanced with social media and made less bureaucratic, cumbersome and officious. It also supports the findings of Adeleke's (2010) study on effectiveness of interactive multi-media (IMM) which arouses interest in learning, positively impact on numeric competences and heightened pupils' interest in computer use and technological bias.

Mazer, Murphy and Simonds (2007) were of the opinion that social media use between teachers and students can improve rapport, motivation and engagement with education. They viewed same as a bridge to enhance interactions of marginalized students with their teacher and increase their confidence in educational activities. It was also thought to facilitate learning and skill development outside formal learning environments by supporting peer-to-peer learning of knowledge and skills, collaboration, diverse cultural expression, the development of skills valued in the modern workplace, and a more empowered conception of citizenship according to Ito, Okabe and Matsuda (2006); Jenkins (2007).

\section{Research Question 2:}

Which social medium or application(s) are utilized in the teaching-learning process of language(s)?

The second research question probed into the choice(s) of social media applicable in the process of teaching and learning at Basics 6-9 schools level in the study area from some twenty-one (21) different applications presented and graphically intimated. The respondents indicated their choices based on acquaintanceships, usages and ease of use. The choices were presented in ranks as depicted in Table 2.

Table 2: Social media applications relevant in teaching-learning process

\begin{tabular}{|c|c|c|c|}
\hline $\mathrm{S} / \mathrm{N}$ & Social media & Percentage (\%) & Rank \\
\hline $\begin{array}{l}1 . \\
2 . \\
3 . \\
4 . \\
5 . \\
6 . \\
7 . \\
8 . \\
9 . \\
10 . \\
11 . \\
12 . \\
13 . \\
14 . \\
15 . \\
16 . \\
17 . \\
18 . \\
19 . \\
20 . \\
21 .\end{array}$ & $\begin{array}{l}\text { BADOO } \\
\text { BAIDU } \\
\text { CLASSMATES } \\
\text { FACEBOOK } \\
\text { GOOGLE+ } \\
\text { INSTAGRAM } \\
\text { LINE } \\
\text { LINKEDIN } \\
\text { MYSPACE } \\
\text { NEXTDOOR } \\
\text { PINTEREST } \\
\text { SKYPE } \\
\text { SNAPCHAT } \\
\text { TELEGRAM } \\
\text { TUMBER } \\
\text { TWITTER } \\
\text { VIBER } \\
\text { WECHAT } \\
\text { WHATSAPP } \\
\text { XING } \\
\text { YOUTUBE }\end{array}$ & $\begin{array}{l}13.5 \\
12.5 \\
13.5 \\
90.0 \\
96.0 \\
79.0 \\
12.5 \\
7.5 \\
7.5 \\
7.0 \\
10.0 \\
23.5 \\
32.5 \\
40.5 \\
7.5 \\
77.5 \\
15.0 \\
15.0 \\
92.5 \\
5.0 \\
94.0\end{array}$ & $\begin{array}{l}11^{\text {th }} \\
12^{\text {m }} \\
11^{\text {th }} \\
4^{\text {th }} \\
1^{\text {st }} \\
5^{\text {th }} \\
12^{\text {th }} \\
14^{\text {th }} \\
14^{\text {th }} \\
15^{\text {th }} \\
13^{\text {th }} \\
9^{\text {th }} \\
8^{\text {th }} \\
7^{\text {th }} \\
14^{\text {th }} \\
6^{\text {th }} \\
10^{\text {th }} \\
10^{\text {th }} \\
3^{\text {rd }} \\
16^{\text {th }} \\
2^{\text {nd }}\end{array}$ \\
\hline
\end{tabular}


The study founds Google+ (1st), You-Tube (2nd), WhatsApp (3rd), Facebook (4th), Instagram (5th) and Twitter (6th) respectively engaged in language education. This indicated that respondents were most comfortable with the above listed among other applications and found them relevant especially in the language learning process. It is necessary to mention that Nextdoor and Xing were least attractive in the study area hence occupied the 15th and 16th ranks respectively.

\section{Research Question 3:}

Is there any relationship between integrated social media and learners' language learning?

The third objective of the study established the relationship between integrated social media and learners' language learning. In order to answer the research question raised, data collected on the integration of social media on students' learning were subjected to Pearson moment correlation and the result is presented in Table 3 .

Table 3: Relationship between Social media and students' learning in language education

\begin{tabular}{|c|c|c|c|c|c|}
\hline Groups & $\mathbf{N}$ & Mean & SD & $\mathbf{r}$ & Sig. (2-tailed) \\
\hline Integration of social media & 670 & 16.38 & 4.48 & 0.245 & .000 \\
\hline Students' language leaming & 670 & 18.62 & 4.14 & & \\
\hline
\end{tabular}

Results in Table 3 showed that there exists a positive relationship between social media and students' language learning among Basics 6-9 school pupils in the study area $(r=0.245, \mathrm{p}<$ $0.05)$.

The result implied that the integration of social media applications into teaching-learning process for Basics 6-9 school pupils will enhance language learning in the study area. In a previous study, Adeleke (2017) found time-on-phone influential on undergraduates academic achievements. His study peered into the perceived direct and indirect influence of smartphones' usage as well as time expended on phone on academic performance. In related terms, this study supported that, social media were preferred and most conveniently accessed on personal smartphones. The end results of the two studies however were at disparity as influence of high time-on-phone across some variables led to low academic achievement but the integration of social media in language education of Basics 6-9 school pupils students has positive connotation. The difference is justiciable in that, exposure to social media is concentrated on language learning and not academic achievement.

\section{CONClusion}

The study concludes that social media integration into teaching-learning activities and especially, in language education is due for application at the Basics 6-9 school pupils' level. Learners are well acquainted with the social media platforms and are being influenced into usage, among other factors by the motive to fight idleness and access learning materials. They even make choices of applications relevant to language learning. 
At this juncture, it is recommended that language education for Basics 6-9 school pupils be treated with Information and Communication Technologies (ICTs) especially, selected and proven Social Media as interface in teaching-learning interactions locally and globally.

\section{REFERENCES}

[1] Adeleke, A. G. (2010) Inducing Technology Bias through Interactive Multi-media in Nigerian Early Childhood Education. Ife Journal of Theory and Research in Education (IJOTRE). 12 (2), pp.105 110 .

[2] Adeleke, A. G. (2016). A Survey of Internet Usage for Learning in Nigerian Secondary Schools. Journal of Media Educational Technology and Communications (JOMETEC), Obafemi Awolowo University, Ile-Ife, Nigeria. 3 (1), pp.102-106.

[3] Adeleke, A. G. (2017). Influence of Time-on-phone on Undergraduates Academic Achievement in Nigerian Universities. American Journal of Educational Research. 5 (5). pp. 564-567.

[4] Available online at http://pubs.sciepub.com/education/5/5/14 DOI:10.12691/education-5-5-14 Boyd, D. M., \& Ellison, N. B. (2008). Social Network Sites: Definition, History, and Scholarship. Journal of Computer-Mediated Communication, 13(1), 210-230.

[5] Ito, M., Okabe, D., \& Matsuda, M. (2006) Personal, Portable, Pedestrian, MIT Press, Massachusetts.

[6] Jenkins, H. (2007) Confronting the Challenges of Participatory Culture: Media Education for the 21st Century, MacArther Foundation, Chicago.

[7] Kaplan, A. M., \& Haenlein, M. (2010). Users of the world, unite! The challenges and opportunities of social media. Business Horizons, 53(1), 59-68.

[8] Lederer, K. (2012). Pros and cons of social media in the classroom. Campus Technology, 25(5), 1-2.

[9] Mazer, J. P., Murphy, R. E. \& Simonds, C. J. (2007) I'll See You On "Facebook": The Effects of Computer-Mediated Teacher Self-Disclosure on Student Motivation, Affective Learning, and Classroom Climate, Communication Education, 56:1, 1-17, DOI: 10.1080/03634520601009710

[10] National Association of School Psychologists. (2016). Using social media in school crisis prevention and intervention: Guidelines for administrators and crisis teams [handout]. Bethesda, MD.

[11] Perkel, D. (2006) "Copy and Paste Literacy: Literacy Practices in the Production of a MySpace Profilee paper presented at Informal Learning and Digital Media: Constructions, Contexts, Consequences, 21-23 September. Available Online: http://people.ischool.berkeley.edu/ dperkel/media/dperkel_literacymyspace.pdf

[12] Uremi, A., Akwaowo, E. \& Senam, N. (2013). Uses and Gratifications of Social Networking Websites among Youths in Uyo, Nigeria. International Journal of Asian Social Science, 3(2). 